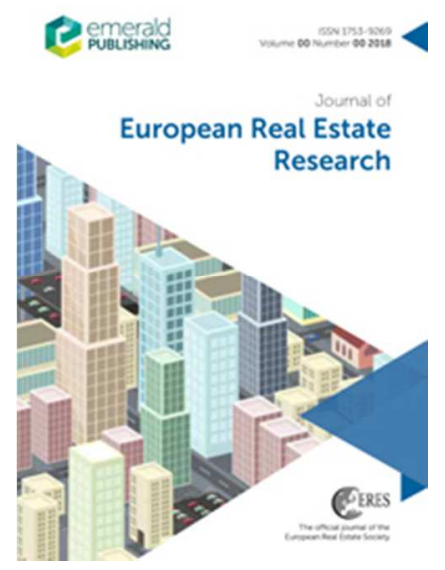

\title{
An Analysis of Regional House Prices in Greece
}

\begin{tabular}{|r|l|}
\hline Journal: & Journal of European Real Estate Research \\
\hline Manuscript ID & JERER-07-2018-0033.R3 \\
\hline Manuscript Type: & Research Paper \\
\hline Keywords: & Greece, Housing, Regional, Panel Estimation \\
\hline \multicolumn{2}{|l}{} \\
\end{tabular}

SCHOLARONE ${ }^{m}$

Manuscripts 


\title{
An Analysis of Regional House Prices in Greece
}

\begin{abstract}
Purpose - This paper examines the housing market in Greece after the Global Financial Crisis focusing on regional analysis and urban markets in Athens and Thessaloniki.

Design/methodology/approach - The paper employs a dataset of over 70,750 property values from 2007 until 2014 incorporating characteristics variables upon which hedonic models are estimated. These form the bases for calculating value indices for mix adjusted houses/apartments by year and region. The indices are used in a panel model in which regional and economic variables are included as independent variables. Using advances in dynamic panel data modelling, a bias-corrected least squares dummy variable model (LSDVC) is applied.
\end{abstract}

Findings - Results indicate the importance of macroeconomic variables in terms of the role of disposable income and significantly different regional effects. Examining the major urban markets, results indicate significant differences in the response of house values to exogenous demand side influences, consistent with the finding of significant regional differences in the LSDVC.

Research limitations/implications - While data on valuations are used that may contain smoothing, the dataset covers a large sample of residential properties. As regional economic differences are significant and persistent, housing markets will also behave differently, and hence national policies, unless targeted, will have regionally differentiated effects.

Practical implications -Regional heterogeneity needs to be considered in model estimation.

Social implications - Policymakers should consider regional differences to improve policy effectiveness.

Originality/value - This is the first paper to use a large sample of residential properties in Greece and apply the LSDVC model to overcome estimation biases.

Keywords Regional Housing markets, Least Squares Dummy Variable Corrected model

Paper type Research paper

Introduction

The housing market in Greece has experienced significant volatility over the past decade. Housing transactions, for example, peaked at around 200,000 in 2006 and fell to 
around 25,000 in 2012. The macroeconomic context since the start of the GFC has been negative impacting both house prices and transactions volumes. Data from the Bank of Greece show property prices falling continually across the country from 2009 to 2014 . In relation to the analysis of the housing market in Greece, there are a relatively small number of studies. More recently Kavarnou and Nanda (2014) conducted a detailed hedonic analysis of factors affecting house prices across Greek islands. They find distinct patterns across islands related to amenity differences and tourism. In this paper we allow for regional variation covering the mainland of Greece in addition to island housing markets and, examine the main urban housing markets in Athens and Thessaloniki. Given the nature of our dataset for the regions of Greece that has significant cross-sectional detail and a more limited time series component $(\mathrm{T}<\mathrm{N})$ we consider the most appropriate panel estimation method and specifically employ a least squares dummy variables corrected (LSDVC) approach. To the best of our knowledge this approach has not been applied previously in an analysis of the housing markets across the country. In the application of the analysis to markets in Athens and Thessaloniki, $\mathrm{N}>\mathrm{T}$ and therefore we use more standard panel methods that have been more commonly applied in the literature.

The paper is structured as follows: next a literature review on housing market research at macro and micro levels is developed. Then we discuss the data and estimation method. This is followed by the results section and the paper finishes with a conclusion and identifies avenues for further research.

\section{Literature Review}

The global financial crisis has had a significant impact on the economy of Greece. Its economic performance has been the worst of southern European economies and this has impacted on the housing market. House prices have been falling continuously since 2009. Estimates for the first three quarters of 2015 also show continuing price falls albeit at a slower rate than in previous recent years.

\section{Table 1: House Price Change (Urban Areas in Greece 2005 - 2014)}

\section{Table 1 about here}

However, Greece is not the only country to have experienced house price reductions. Within the Eurozone other countries that have seen large price falls include France, Ireland, Italy, Portugal and Spain. In the rest of the EU, Denmark and the UK have also experienced falling prices. Most of these countries began to see house price increases. UK house prices have been rising since late 2012 and this has persisted throughout 2015 and into 2016. Ireland has also seen price rises in 2014 and 2015 continuing into 2016. In addition to periods of falling house prices, there have also been significant reductions in transactions volumes. Falling transactions predate falling housing prices in Greece. In 2008 transactions $^{1}$ fell by almost $22 \%$ from 2007 while prices showed a small increase. This was followed by a reduction of nearly 36\% in transactions in 2009 .

\footnotetext{
${ }^{1}$ Data from Bank of Greece
} 
Transactions remained flat in 2010 but then fell by over $42 \%$ in 2011 and then by approximately $27 \%$ and $22 \%$ in 2012 and 2013 respectively.

Such reductions have implications for modelling. For research at a disaggregated level, very small samples can emerge that may have a different composition of properties in, say, 2014, compared with 2007. Usually it is easier to sell 'lemons' in good markets than bad markets and hence the quality mix will vary counter-cyclically.

The long and significant downward trend in house prices reflects the economic crisis exacerbated by imposed austerity policies. However fiscal policy measures have a differential impact across different regions as regions vary in the extent of exposure to public expenditure either directly through public sector employment or via transfer payments, varying as a proportion of regional income. Monastiriotis (2011) argues that economic activity in Greece is more spatially concentrated than in other countries in Europe. He states that, "Attica, the broader region of the capital Athens, [accounts] for some $40 \%$ of population and almost $50 \%$ of national gross domestic product." (p2) He notes that other regions of Greece have low industry specialisations, focusing mainly in agriculture and tourism. Finance and business services account for less than $5 \%$ of regional economies outside of Athens and Thessaloniki. These structural economic differences suggest that a blanket introduction of national austerity policies will have regionally differentiated effects. Monastiriotis argues that the impact of austerity coupled with structural imbalances across regions could generate permanent effects on local/regional economies particularly when there are weak or limited cross-regional equilibrating mechanisms (via labour mobility, price adjustment). This in turn may have implications for the pattern of regional house prices and cause differential house price movements over time. Reductions in public sector employment, pay levels, pensions and social security payments impact differentially across regions. Monastiriotis argues that a "Myrdalian-type circular causation effect may well kick-in, at least in the most heavily affected regions, where internal demand recedes the most." (p9) Further, and "consistent with the Kaldorian view of cumulative causation, a drop in the mass or density of economic activity in these regions will lead to a relative reduction in economic efficiency and in private returns (wages and profits), thus reinforcing the tendency for out-migration (brain-drain) and disinvestment. As a result, growth differentials between the better-off and the less well-off regions will tend to become permanent, even if the initial conditions that generated them (that is, the austerity measures) disappear." (Op. Cit., p10) Challenging neo-classical growth theory, such permanent effects could be argued to be more likely when there are weak equilibrating mechanisms across regions that characterise Greece. Such changes in the regional economies of Greece have implications for house prices and the future evolution of prices that could impact on relative regional house price differences. Leung (2014) examines the relationship between house prices and economic fundamentals considering mis-pricing and error correction dynamics. Using a DSGE model he finds that changes in house prices depend on the acceleration of the house price to income ratio, a ratio that can vary regionally. Leung and Teo (2011) note that significant interregional house price differences exist within countries. These differences relate not only to levels of house prices but also to their volatilities. Clark and Coggin (2009) examine regional house price cycles in the US. They found that the US comprised two major groups of regions that had different house price cycles. Chowdhury and Maclennan (2014) examine the duration and magnitude of regional house price cycles in the UK 
using a Markov switching VAR model. Their research identifies two super-regions that are broadly consistent with a north-south split in the UK housing market. Super region one (southern) was found to have faster house price growth than super region two (northern) for medium and high house price appreciation regimes. Further, the duration of positive growth rate regimes was longer in the southern super region than in the northern super region.

In addition to observed house price change and changes in transactions volumes as well as forecasting future price performance, lies the attitude to houses and homeownership. Gounopoulos et al (2012) suggest that, "the housing market in Greece is one where demand has typically risen faster than supply, house prices have been extremely inflexible downwards, and house purchases have largely related to consumption. Greek households have traditionally treated housing as consumption good and have adopted a conservative and less risky, 'buy and hold' approach, which has arguably been responsible for steadily rising house prices. Recently, however, particularly with the stock market boom of the late 1990s, there have been signs that household attitudes towards housing may be changing." (p550) The authors suggest that there may be more of an investment motive in housing transactions and that this could be seen as beneficial as it would increase the number of properties coming onto the market. However, if prices fall, this could discourage investors from selling as they could adopt a 'wait and see' strategy particularly if holding is not too costly.

House price change has a major impact on wealth and perceived wealth in many countries. The subsequent macroeconomic impact can be significant particularly where the rate of homeownership is high. Katrakilidis and Trachanas (2012) note that housing contributes between $80-90 \%$ of household wealth. In addition, Greece has a very high homeownership rate of almost $80 \%$ of all households. Demary (2010) examined the interaction between house prices and the macroeconomy in a cross-country study. His findings proved the existence of housing wealth effects and interactions between house prices and interest rates. Case, Quigley, and Shiller (2003) found wealth effects that lead to changes in consumption with subsequent impacts on the macroeconomy.

Factors affecting house price inflation have been the focus of numerous studies in different countries. For Greece, Apergis and Rezitis (2003) analyse the impact of a range of macroeconomic variables on new house prices including inflation, employment, money supply and loans for house purchase. Their results indicated that mortgage rates and employment had greater effects on house prices than changes in money supply or inflation. Lastrapes (2002) found that money supply affected real house prices while Greiber and Setzer (2007) found that liquidity was important for new housing supply and hence house prices. They identified money demand, asset price and credit channels. In contrast, Merikas et al. (2009) using the macroeconomic variables of inflation, unemployment, interest rates, an index of national production and the Athens stock exchange index, found that inflation was the most important driver of house prices rather than measures of liquidity.

Taltavull and White (2016) examine the role of liquidity in the housing markets of Spain and the UK specifically focusing on how the asset price channel passes changes in money supply to house prices. They note that the European Commission has acknowledged the impact of house prices on the macroeconomy with house price 
indices included to indicate one of the dimensions of macroeconomic imbalances. Further they note that changes in the financial system have led to increased liquidity as a result of deregulation and the creation of the Eurozone. Taltavull and White use a VAR and VECM approach in different steps of model estimation. Liquidity affects house prices in Spain through the house price and migration equations in their model. In the UK the effect of liquidity is through income and the labour market rather than directly via house prices.

Kajuth et al (2016) examine house prices in Germany using regional level data considering the role played by financial variables following from monetary policies adopted in the Euro area after the financial crisis. They found that apartment prices were overvalued across the whole country but not for single family home prices. Residential property prices were found to be overvalued in larger cities but not across the whole country. Misalignment of property prices was found to be exacerbated by lower interest rates.

In relation to the role of lending for house purchase, Brissimis and Vlassopoulos (2008) analyse Greek mortgage markets and find a bi-directional relationship between mortgage lending and house prices, at least in the short run. Belke et al (2008) analysed global liquidity and its impact on house prices for OECD countries. They found that liquidity spillovers existed and impacted asset price inflation. House prices were found to react to global liquidity supply. In addition, increased house prices raised liquidity further and increased the demand for credit.

In many studies income, is found to have a significant influence on house prices (e.g., Hort, 1998; Meen 2002). More recent research by Kishor and Marfatia (2016) considers whether exogenous variables have permanent or transitory impacts on house prices. Their results across OECD countries found that house price cycles and income cycles have similar dynamic patterns and a positive correlation between income and house prices. A positive relationship between house prices and income and a negative relationship between house prices and interest rates was found to hold in the long run (permanent effects). House prices were found move in the short run to adjust back to equilibrium. Short run changes in house prices were independent of changes in income and interest rates.

Data and Method

The dataset employed contains over 70,750 observations ${ }^{2}$ on individual property valuations and characteristics. Valuations were conducted by the Eurobank Property Services valuation department and are the basis for the dependent variable in the subsequent analysis and for the construction of the hedonic index. While the time period covered is mainly one affected by the impact of the GFC on the Greek economy, individual house valuations cover the entire country. One caveat is that the number of transactions fall as the economic crises deepened which implies that for some smaller locations with lower populations, samples sizes may be very small and given the heterogeneity of the housing stock can therefore be unrepresentative and therefore

\footnotetext{
${ }^{2}$ We are grateful to Eurobank Property Services for supplying the data for this study.
} 
provide potentially biased results in model estimation. In an attempt to obviate this, we provide an analysis at regional level and use pooled cross-sections.

Figures 1 and 2 show house price indices for regions of Greece from 2007 to 2014 .

Figure 1: House Price Indices for Regions of Greece

Figure 1 about here

Figures 1 and 2 both reveal significant reductions in house prices across the mainland and islands of Greece. Sterea Ellada sees the largest proportionate drop in price while Western Macedonia has one of the smallest proportionate falls in house prices by the end of the time period. Results for Eptanisa in figure 2 suggest that prices stop falling around 2012, stabilise in 2013 and being to increase in 2014, and therefore show a very different performance from other regions in Greece towards the end of the time period observed. This, however, may reflect a very limited number of transactions.

Figure 3 shows house prices in Athens and its suburbs. Again, all subdivisions display falling prices particularly over the second half of the time period covered. The downward trend continues to the end of the data period in 2014.

Figure 4 shows regional GDP for a subset of the regions in the earlier figures. These areas are Athens (EL30), Central Macedonia (EL12), Sterea Ellada (EL24), and Crete (EL43). The magnitude of the overall fall in GDP is large, between 25 to $30 \%$ across the four areas presented.

Figure 2: House Price Indices for Regions and Island Groups of Greece

Figure 2 about here

Figure 3: House Prices in Athens \& Suburbs, 2007 - 2014

Figure 3 about here

Figure 4: Regional GDP 2007 - 2014 (Left-hand scale for Athens, EL30)

Figure 4 about here

Using individual house valuations, there is a potential issue of heterogeneity and specifically unobserved heterogeneity. The simplest approach to modelling heterogeneity is to assume that each individual has his or her own specific intercept, $f_{i}$. Thus, we have $\mathrm{N}$ separate parallel regression lines. The "fixed effects" model is:

$y_{i, t}=x_{i, t} \beta+f_{i}+\epsilon_{i, t}$ 
Random errors are $\rho$, the individual specific effects, and $\varepsilon_{i t}$, the white-noise innovations. Given that our dependent variables is based upon residential property valuations and given that these may lag market change, the AR(1) specification may be appropriate. OLS estimation of (4) will yield inconsistent estimators. "Also the least-squares estimator for $\rho$ obtained after removing the individual effects from the model by taking deviations from the mean per individual over the time-series observations, known as the least-squares dummy variable estimator (LSDV) or within groups estimator, is inconsistent unless $T \rightarrow \infty$." (Kiviet, 2005, p10) However its standard deviation can be significantly less than that obtained from "the simple Anderson-Hsiao Instrumental Variables (IV) estimators of the model in first differences and for various Generalized Method of Moments (GMM) estimators." (Kiviet, 1995, p55) If, by correcting the bias in the LSDV estimator, "the resulting corrected estimation procedure has minor bias and still a relatively small standard deviation, then, on a mean squared error criterion, this corrected LSDV [LSDVC] estimator can be more efficient in finite samples than instrumental variable estimators and possibly even better than (asymptotically efficient) GMM estimators." (Op. Cit., p55)

Panel models may also be based upon random effects. In the random effects model, the individual-specific effect is a random variable that is uncorrelated with the explanatory variables. In the fixed effects model, the individual-specific effect is a random variable that is allowed to be correlated with the explanatory variables. Fixed effects models 
control for, or partial out, the effects of time-invariant variables with time-invariant effects.

We use fixed effects when we want to analyse the impact of variables that vary over time. For time invariant characteristics, fixed effects assumes that these are unique for each observation and should not be correlated with other observations. Since we have hedonic data for individual houses that do not necessarily vary over time but may be similar across observations, we can construct hedonic models from which we extract estimated survey values across locations and time periods. The hedonic regression below shows the format of the model and independent variables used to explain log real house survey values.

Panel datasets combine a time dimension ( $\mathrm{T}$ ) and an individual (cross-sectional) dimension (N). Macroeconomic panels usually have greater time dimensions than individual dimensions. However, this may not always be the case as with the Greek data used in this study. This difference (whether or not $\mathrm{T}>\mathrm{N}$ ) is important when considering estimation techniques. For example, using dummies to capture regional effects gives biased estimates in models that include the lagged dependent variable as an independent variable when the panel has a short time dimension. This bias approaches zero when the time dimension approaches infinity (Nickell, 1981). Estimation techniques used in microeconomics (that use panel data more heavily) may not be appropriate for macroeconomic panels. Researchers have suggested that the characteristics of data influence an estimator's performance. Judson and Owen (1996) examine a range of techniques for dynamic panel model estimation. They summarise their research stating that least squares dummy variable bias may not be insignificant even for as much as 30 time periods. They note that, "a 'restricted GMM' estimator that uses a subset of the available lagged values as instruments increases computational efficiency without significantly detracting from its effectiveness." (p2) They further note that when the panel time dimension is small that results suggest that a corrected least squares dummy variable approach is best. As the time series dimension lengthens, the Anderson-Hsiao estimator is found to perform at least as well. Bun and Kiviet (2002) found increased bias of GMM estimators when the number of moment conditions increased.

Bun and Carree (2005) develop a bias-corrected estimator for situations in which $\mathrm{N}$ is large relative to $\mathrm{T}$ for fixed effects panel models. "It is computed as a bias correction to the LSDV estimator and as such is related to estimators developed by Kiviet (2005), ..." (Op. Cit., p200). They indicate that their approach is preferable as Kiviet's estimator requires a preliminary consistent estimator to evaluate the extent of bias. Therefore, the accuracy of this estimator would be affected by the preliminary estimator that has been used. Further, it should be noted that bias-corrected estimators are, "derived under certain restrictive assumptions, including strict exogeneity of regressors, ..., homoscedasticity of the disturbances, and balanced panels. (Bun and Carree, 2005, p209).

Hahn and Kuersteiner (2002) developed a bias-corrected estimator related to Kiviet (1995) however, this is not appropriate for small T. Bun and Carree (2006) extend their earlier work to consider biased correction using panel data where heteroscedasticity is present in cross sections and time series'. Phillips and Sul (2007) examine bias in panel 


\section{Results}

In the first stage of estimation, hedonic models are estimated in order to create house price indices over the time period available in the data set. The standard hedonic model takes the following format:

House Value $e_{1}=\alpha_{0}+\alpha_{1}$ Area $+\alpha_{2}$ House $+\alpha_{3}$ Apartment $+\alpha_{4}$ Medium Heating $+\alpha_{5}$ Gas Heating $+\alpha_{6}$ Good Built $+\alpha_{7}$ Very Good Build $+\alpha_{8}$ Bed $2+\alpha_{9}$ Bed $3 p+\alpha_{10}$ Bath $2 p+\alpha_{11}$ Built 1950s + $\alpha_{12}$ Built 1960s $+\alpha_{13}$ Built 1970s $+\alpha_{14}$ Built 1980s $+\alpha_{15}$ Built 1990s $+\alpha_{16}$ High Density + $\alpha_{17}$ Distance from CBD $+\alpha_{18}$ Touristic Hotspot $+\alpha_{19}$ Elevator $+\alpha_{20}$ View $+\varepsilon_{i}$

Where the ith house value is regressed on house size (area), the type of property (house, apartment),type/quality indicators for heating and building standard, the number of bedrooms (either 2 bed (Bed2) or 3 or more bedrooms (Bed3p)), two or more bathrooms (Bath2p), and the decade in which the property was built. The dataset also contains measures capturing building density, distance from the relevant central business district, whether the property is in a touristic hotspot and has a view and if the building has an elevator.

Table 2 below shows a typical hedonic model, in this case applied to the national dataset $^{3}$. These are repeated for each region covered (NUTS 2 classification) and are available in the appendix.

The hedonic regression (based upon property and the property's location characteristics) indicates strong effects from high density, touristic locations, good build quality, views, and age of property, where older properties are much less expensive relative to the excluded category of properties built since 2000. Size of property has a positive and non-linear effect, showing that prices rise but at as decreasing (small but significant) rate as size increases. Both property and locational amenity effects are found to be significant. The regional model results are broadly consistent with those

3 Individual regional models are available from the authors on request 
found for the national level model. Touristic hotspot is not always significant, however this may be due to the regional composition of Greece and the level of disaggregation.

The hedonic variables will not appear in the LSDVC model due to their time invariance. Instead macroeconomic and regional variables are included. The time dimension requires consideration of time series properties of variables, specifically unit roots and stationarity issues. House price and GDP trends in the figures above suggest mean values that are time varying. In addition the autoregressive characteristics of valuations mean that it is appropriate to employ the AR(1) modelling approach.

The dataset we use has a relatively short time series component, Gutierrez (2003) suggests that the Pedroni (1999) panel $\rho$-statistic and group $\rho$-statistic have low power in panels with small T. Pesaran (2012) notes that “... with T small (say around 15), it is only possible to devise sufficiently powerful unit root tests which are informative in some average sense, namely indicating whether the null of a unit root can be rejected in the case of a significant fraction of the [regions] in the panel." (p546)

Table 2: Hedonic House Value Model: (2007-2014) for Greece (70,750 observations)

Table 2 about here

Estimated house values across locations and time periods are constructed from the model above for each region included in the panel model below in table 4 .

Before this we test for unit roots in the aggregated time series variables namely the house valuation index and household disposable income. We use the procedure of Levin and Lin (1993) that is applied to panel data. They consider three variants distinguished by the deterministic variables that are included (i.e., a model without a constant, one with a constant and another with a constant and a time trend). Their estimated equation is:

$$
\Delta x_{i t}=\delta_{i} x_{i t-1}+\sum_{L=1}^{p_{i}} \delta_{i L} \Delta x_{i t-L}+\delta_{m i} d_{m t}+\mu_{t}
$$

where $i$ represents the region or panel to be examined, $x$ is the variable of interest, and $d$ is the deterministic variable. More recent work has been conducted by Levin, Lin and Chu (2002) on panel unit root tests. Testing the null hypothesis of non-stationarity requires the residuals from this regression to be normalized in order to control for inter-regional heterogeneity. We normalize by scaling the residuals by the standard error from the regression. These results for model (6) are reported for all regions combined and presented in table 3 below. These results suggest that the panel variables are stationary in first differences.

Table 3: Levin, Lin \& Chu Panel Unit Root Test

Table 3 about here 
Next, we focus on analysing Athens and Thessaloniki as these cities provide the majority of all transactions in Greece.

For these cities the time component is longer than the cross sectional component and therefore we no longer apply LSDVC.

Table 5: Athens

\section{Table 5 about here}

The results for Athens including the suburbs are presented in table 5 above. The adjusted R-square is high, which is not uncommon for this type of model. GDP is positively statistically significant while unemployment is negatively significant. The housing investment and loans variables do not significantly impact on house price. The fixed effects capture the suburbs of the city and are all significant. It is also notable that they are within one standard deviation of each other.

Table 6 below presents the results for Thessaloniki.

Table 6: Thessaloniki

Table 6 about here

For Thessaloniki, Gross Value Added (GVA) is positively significant while the other variables are negatively significant. This seems counterintuitive for housing investment and loans. The fixed effects capturing the suburban markets are all significant although statistically close to each other. Coefficients on variables that are the same or similar between Athens and Thessaloniki (the demand side variable GDP or GVA, and unemployment) have quite different coefficients reflecting different sensitivities of house prices to these key demand drivers. 


\section{Conclusion and Discussion}

This is the first time, to the best of our knowledge, that a regional house value panel model has been constructed for Greece based upon a large micro dataset of house/apartment valuations. In addition, this is the first study of its kind to apply a LSDVC estimation approach to regional housing markets in Greece. The panel model presented above is based upon a regional disaggregation. Macroeconomic variables are highly significant as are almost all regional variables. Despite similarities in house value and GDP trends, differences between regions seems highly significant even for those that are close spatially and where there is a concentration of population and economic activity (Athens and Attica). This may have important policy implications and regional targeting of policy may need to be considered to improve effectiveness.

Differences may also exist at smaller spatial scales. Disaggregating further to NUTS3 is potentially possible for some but not all locations due to data restrictions in relation to numbers of properties upon which valuations have been placed.

During the time period covered, the data reflect falling house prices (perhaps not surprising) but the number of transactions is very volatile. It is worth bearing in mind that this could imply that the mix of properties on the market changed over the time period covered. This would, in turn, create another source of heterogeneity.

In addition, in relation to the dependent variable, survey value, this does not necessarily equal a selling price (or asking price). Market participants and valuers might be slow to adjust price expectations initially and price or value setting would rely on recent past observations suggesting an anchoring effect and a smoothing and lagging effect in the data. In fact, transactions seem to fall before valuations show any significant change, only really showing a large fall from 2011 to 2012, and then a bigger fall from 2012 to 2013.

Forecasts of future regional house price evolution may have to consider whether or not changes to regional economies (due to austerity policies) cause a permanent change in income growth rates, as outlined in the discussion above, in addition to any changes in supply side responsiveness. If the latter is unchanged then future house price rises in some regions that have been most severely affected by the GFC and austerity programmes may be smaller than would have been the case after previous recessionary periods. Again, this calls for regionally differentiated policy interventions.

Moving to estimated generalised least squares (EGLS) and seemingly unrelated regression (SUR) models provide results for the largest markets of Athens and Thessaloniki. For each city, the fixed effects are statistically similar across the contiguous housing submarkets while there are significant differences in the response of house values to the demand side variables. This highlights significant heterogeneity across the two major housing markets in Greece. Consistent with the LSDVC model, this finding also reinforces the importance of a disaggregated analysis of housing markets within Greece. 
Future research could usefully disaggregate to NUTS3 and consider spatial relationships. From a policy perspective however, the notable regional differences across Greece uncovered in this research suggest that regionally differentiated policies would be more effective at raising regional incomes than national level policies alone. 
References

Apergis, N. and Rezitis, A. (2003) Housing prices and macroeconomic factors: prospects within the European Monetary Union. Applied Economic Letters, 10(12), 799-804.

Brissimis, S.N. and Vlassopoulos, T. (2008) The interaction between mortgage financing and housing prices in Greece. The Journal of Real Estate Finance and Economics 39, 146164.

Bun, M.J.G. and Carree, M.A. (2005) Bias-Corrected Estimation in Dynamic Panel Data Models, Journal of Business and Economic Statistics, 23(2), 200-210.

Bun, M.J.G. and Carree, M.A. (2006) Bias-Corrected Estimation in Dynamic Panel Data Models with Heteroscedasticity. Economic Letters, 92, 220-227.

Bun, M.J.G. and Kiviet, J.F. (2002) The Effects of Dynamic Feedbacks on LS and MM Estimator Accuracy in Panel Data Models, UvA-Econometrics Discussion Papers 2002/05, University of Amsterdam

Chowdhury, R.A. and Maclennan, D. (2014) Regional House Price Cycles in the UK, 19782012: A Markov Switching VAR. Journal of European Real Estate Research, 7(3), 345-366.

Clark, S. and Coggin, T. 92009) Trends, Cycles and Convergence in the US Regional House Prices. Journal of Real Estate Finance and Economics, 39(3), 264-283.

Demary, M. (2010). The interplay between output, inflation, interest rates and house prices: International evidence. Journal of Property Research, 27(1), 1-17.

Gounopoulos, D., Merikas, A.G., Merika, A.A. and Triantafyllou, A. (2011) Explaining House Price Changes in Greece, Applied Financial Economics, 22(7), 549-561.

Greiber, C. and Setzer, R. (2007) Money and Housing - Evidence for the Euro Area and the US. Deutsche Bundesbank.

Gutierrez, L. (2003) On the power of panel cointegration tests: a Monte Carlo comparison, Economic Letters, 80, 105-111.

Hahn, J. and Kuersteiner, G. (2002) Asymptotically Unbiased Inference for a Dynamic Panel Model with Fixed Effects when Both N and T are Large. Econometrica, 70, 16391657.

Hort, K. (1998) The Determinants of Urban House Price Fluctuations in Sweden 19681994. Journal of Housing Economics, 7(2), 93-120.

Judson, R.A. and Owen, A.L. (1996) Estimating Dynamic Panel Data Models: A Practical Guide for Macroeconomists. Federal Reserve Board of Governors, Washington D.C. 
Kajuth, F., Knetsch, A. and Pinkwart, N. (2016) Assessing House Prices in Germany: Evidence from a Regional Data Set. Journal of European Real Estate Research, 9(3), 286307.

Kavarnou, D. and Nanda, A. (2014) Which Attributes Influence the Housing Markets across the Greek Islands? Journal of Real Estate Literature, 22(2), 233-260.

Kishore, N.K. and Marfatia, H.A. (2016) The Dynamic Relationship Between Housing Prices and the Macroeconomy: Evidence from OECD Countries. Journal of Real Estate Finance and Economics (2016) doi:10.1007/s11146-015-9546-8

Kiviet, J.F. (2005) Judging Contending Estimators by Simulation: Tournaments in Dynamic Panel Data Models, Tinbergen Institute Discussion Paper, TI 2005-112/4

Kiviet, J.F. (1995) On Bias, Inconsistency, and Efficiency of Various Estimators in Dynamic Panel Data Models, Journal of Econometrics, 68, 53-78.

Leung, C.K.Y. (2014) Error Correction Dynamics of House Prices: An Equilibrium Benchmark. Journal of Housing Economics, 25, 75-95.

Leung, C.K.Y. and Teo, W.L. (2011) Should the Optimal Portfolio be Region-Specific? A Multi-Region Model with Monetary Policy and Asset Price Co-Movements. Regional Science and Urban Economics, 41, 293-304.

Levin, A. and Lin, C. F. (1993). 'Unit Root Test in Panel Data: New Results', University of California at San Diego, Discussion Paper No. 93-56.

Levin, A., Lin, C.F., and Chu, C.S.J. (2002) Unit root tests in panel data: Asymptotic and finite-sample properties. Journal of Econometrics, 108: 1-24.

Meen, G. (2002) The Time-Series Behavior of House Prices: A Transatlantic Divide? Journal of Housing Economics, 11(1), 1-23.

Merikas, A.G., Triantafyllou, A. and Merika, A.A. (2009) Explaining house price changes in Greece. Paper Presented at the European Financial Management Association Annual Meeting, Milan.

Monastiriotis, V. (2011) Making Geographical Sense of the Greek Austerity Measures: Compositional Effects and Long-Run Implications, Cambridge Journal of Regions, Economy and Society, 1-15.

Nickell, S. (1981) Biases in Dynamic Models with Fixed Effects, Econometrica, 49, 14171426.

Pedroni, P. (1999) Critical values for cointegration tests in heterogeneous panels with multiple regressors. Oxford Bulletin of Economics and Statistics November (Special Issue), 653-669. 
Pesaran, M.H. (2012) On the Interpretation of Panel Unit Root Tests. Economic Letters, $116,545-546$.

Phillips, P.C.B. and Sul, D. (2007) Bias in Dynamic Panel Estimation with Fixed Effects, Incidental Trends and Cross Section Dependence. Journal of Econometrics, 137, 162-188.

Taltavull de La Paz, P. and White, M. (2016) The Sources of House Price Change: Identifying Liquidity Shocks to the Housing Market. Journal of European Real Estate Research 9(1), 98-120. 
Table 1: House Price Change (Urban Areas in Greece 2005 - 2014)

\begin{tabular}{|c|c|}
\hline Year & House Price Change (\%) \\
\hline 2005 & 10.9 \\
\hline 2006 & 13.0 \\
\hline 2007 & 6.2 \\
\hline 2008 & 1.5 \\
\hline 2009 & -4.3 \\
\hline 2010 & -4.4 \\
\hline 2011 & -5.5 \\
\hline 2012 & -11.8 \\
\hline 2013 & -10.9 \\
\hline 2014 & -7.9 \\
\hline
\end{tabular}

Source: Bank of Greece

Figure 1: House Price Indices for Regions of Greece

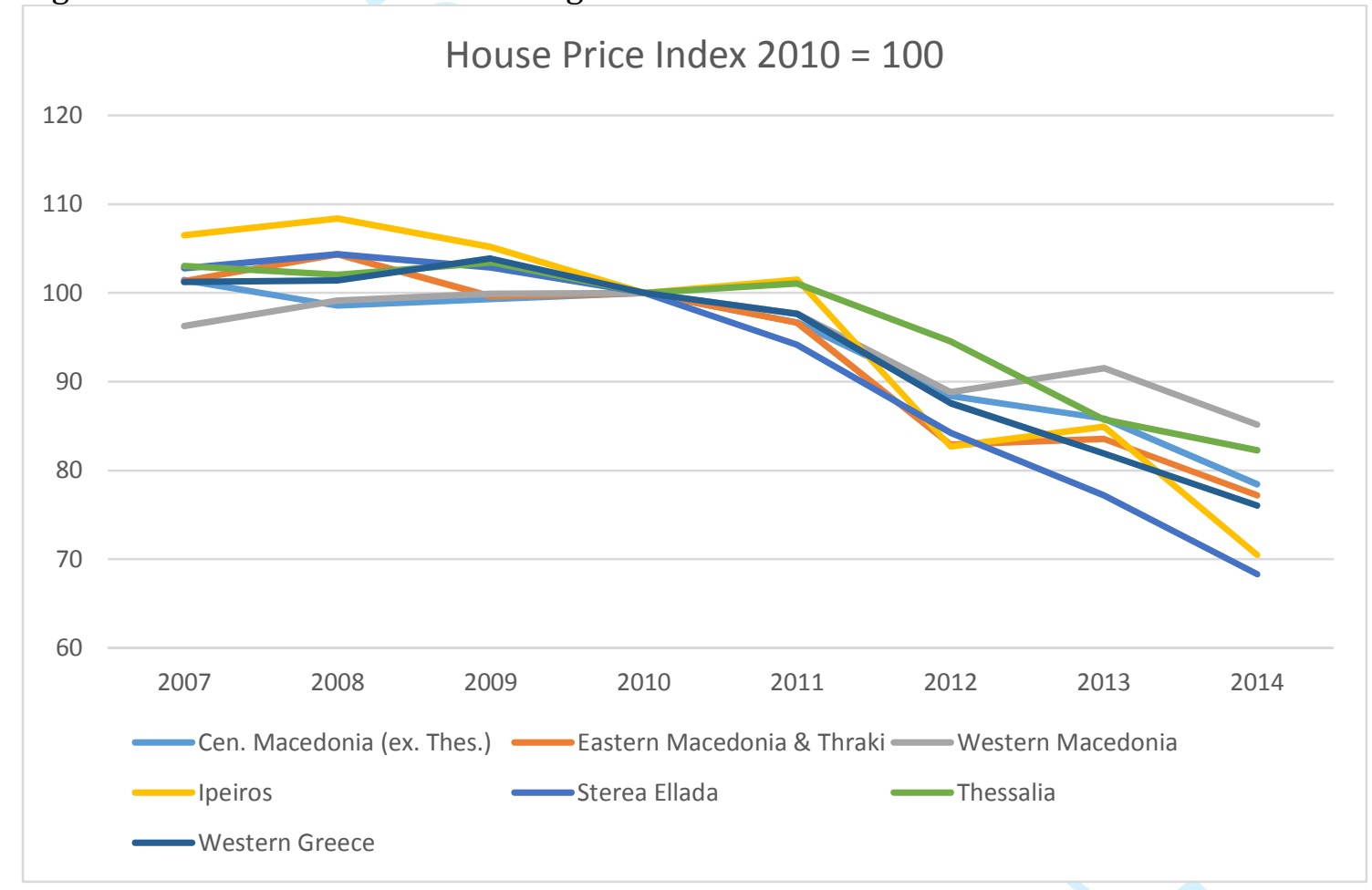


Figure 2: House Price Indices for Regions and Island Groups of Greece House Price Index $2010=100$

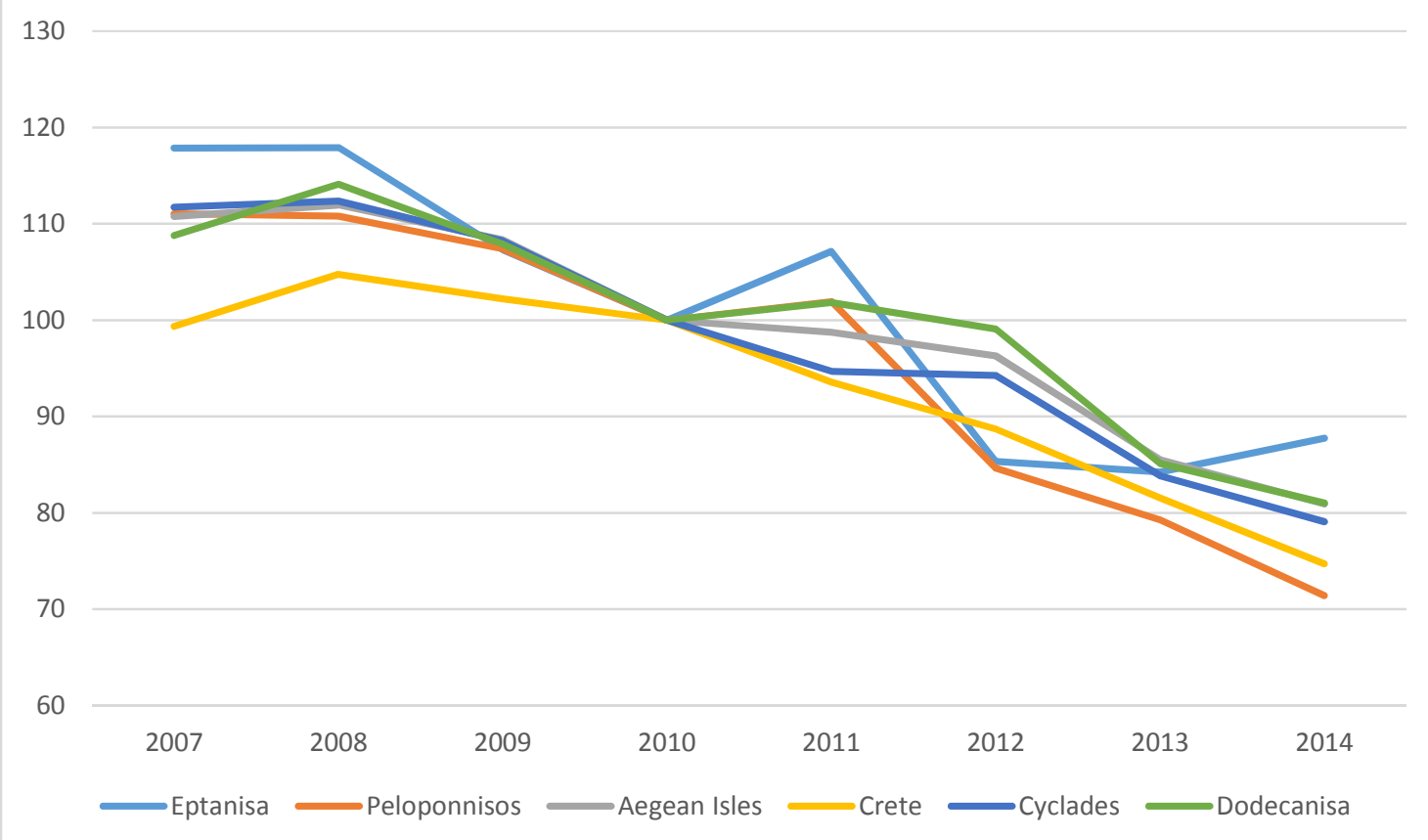

Figure 3: House Prices in Athens \& Suburbs, 2007 - 2014

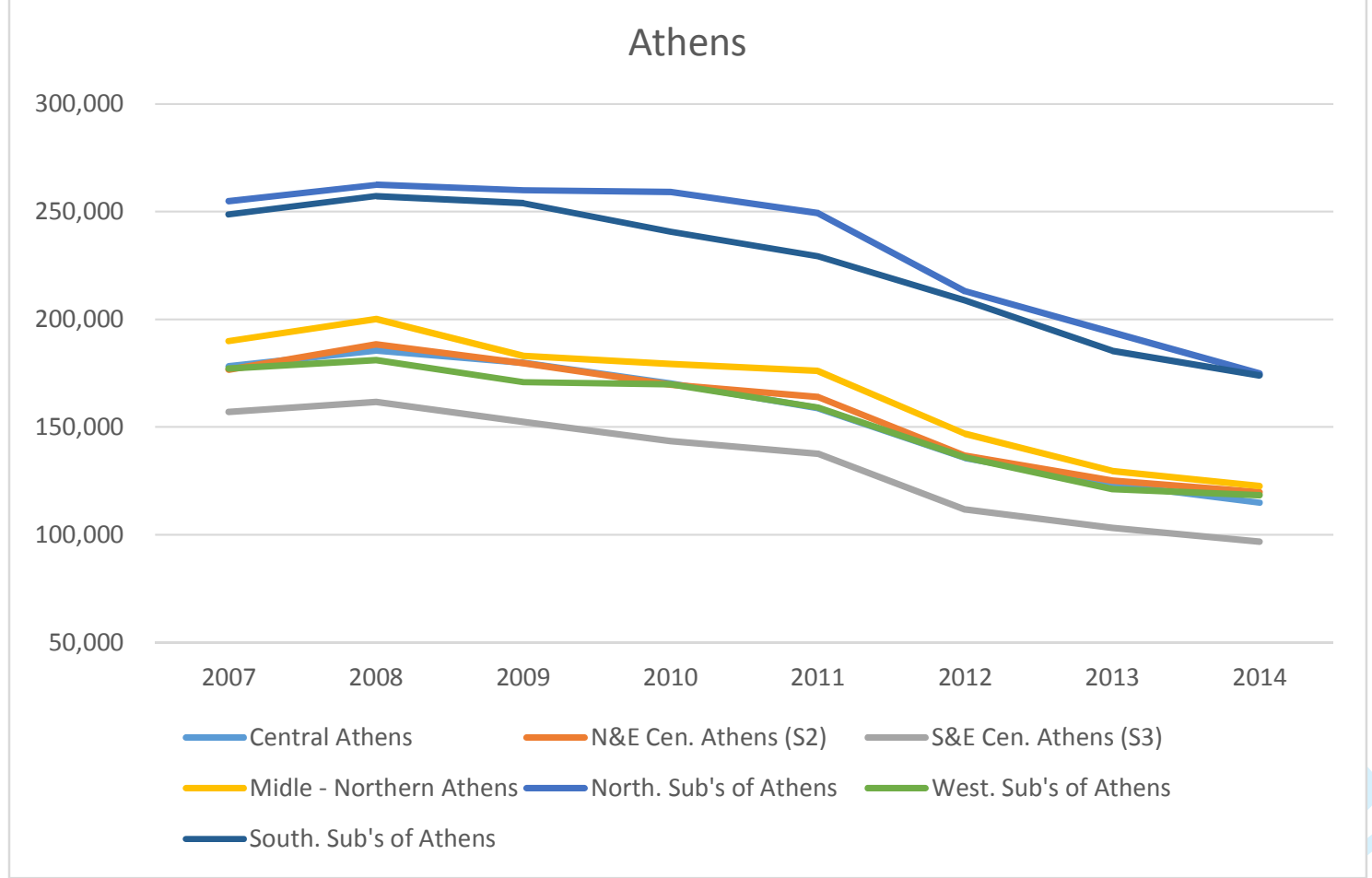


1

2

3

4

5

6

7

8

9

10

11

12

13

14

15

16

17

18

19

20

21

22

23

24

25

26

27

28

29

30

31

32

33

34

35

36

37

38

39

40

41

42

43

44

45

46

47

48

49

50

51

52

53

54

55

56

57

58

59

60

Figure 4: Regional GDP 2007 - 2014 (Left-hand scale for Athens, EL30)

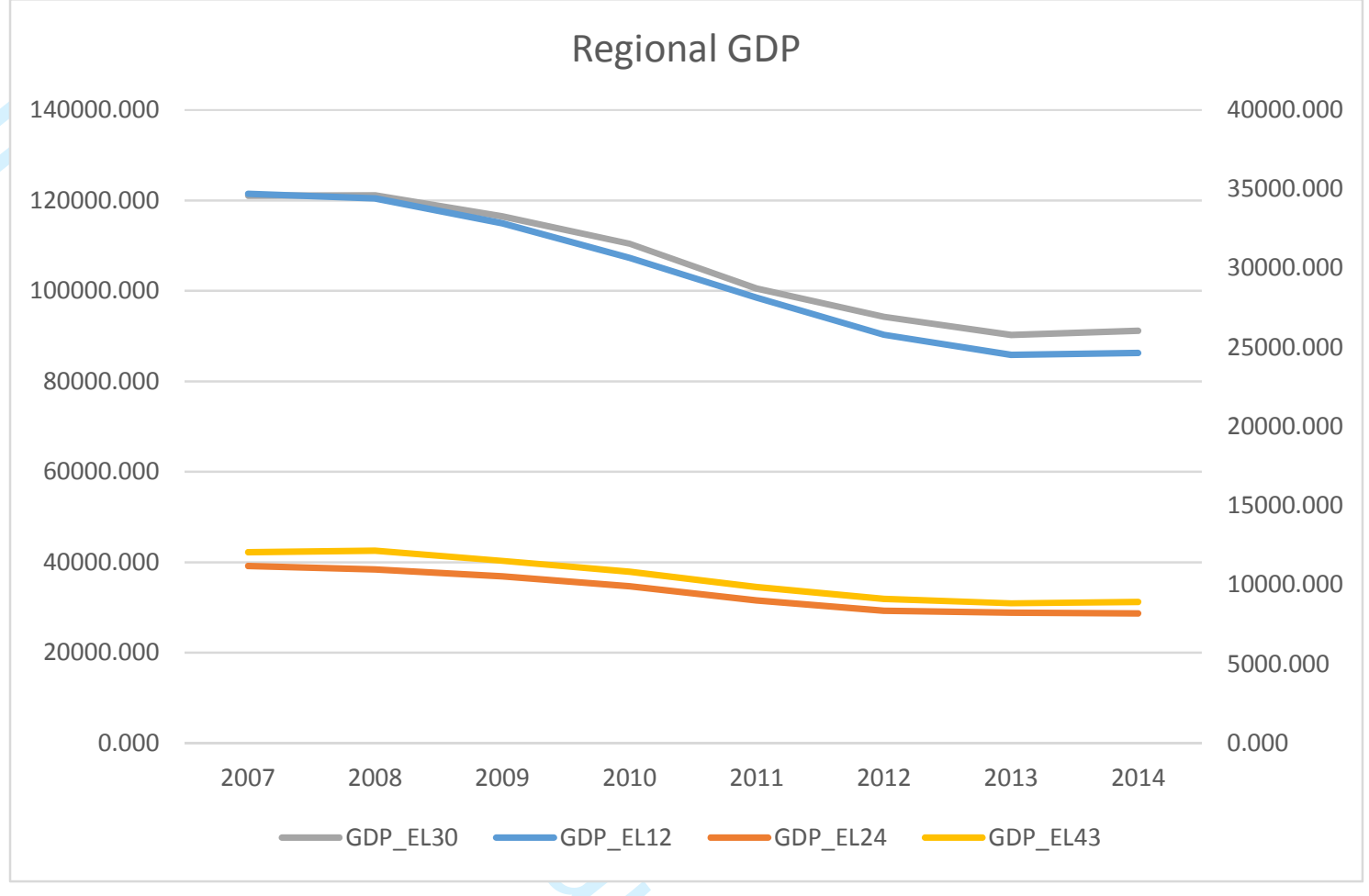


Table 2: Hedonic House Value Model: (2007-2014) for Greece (70,750 observations)

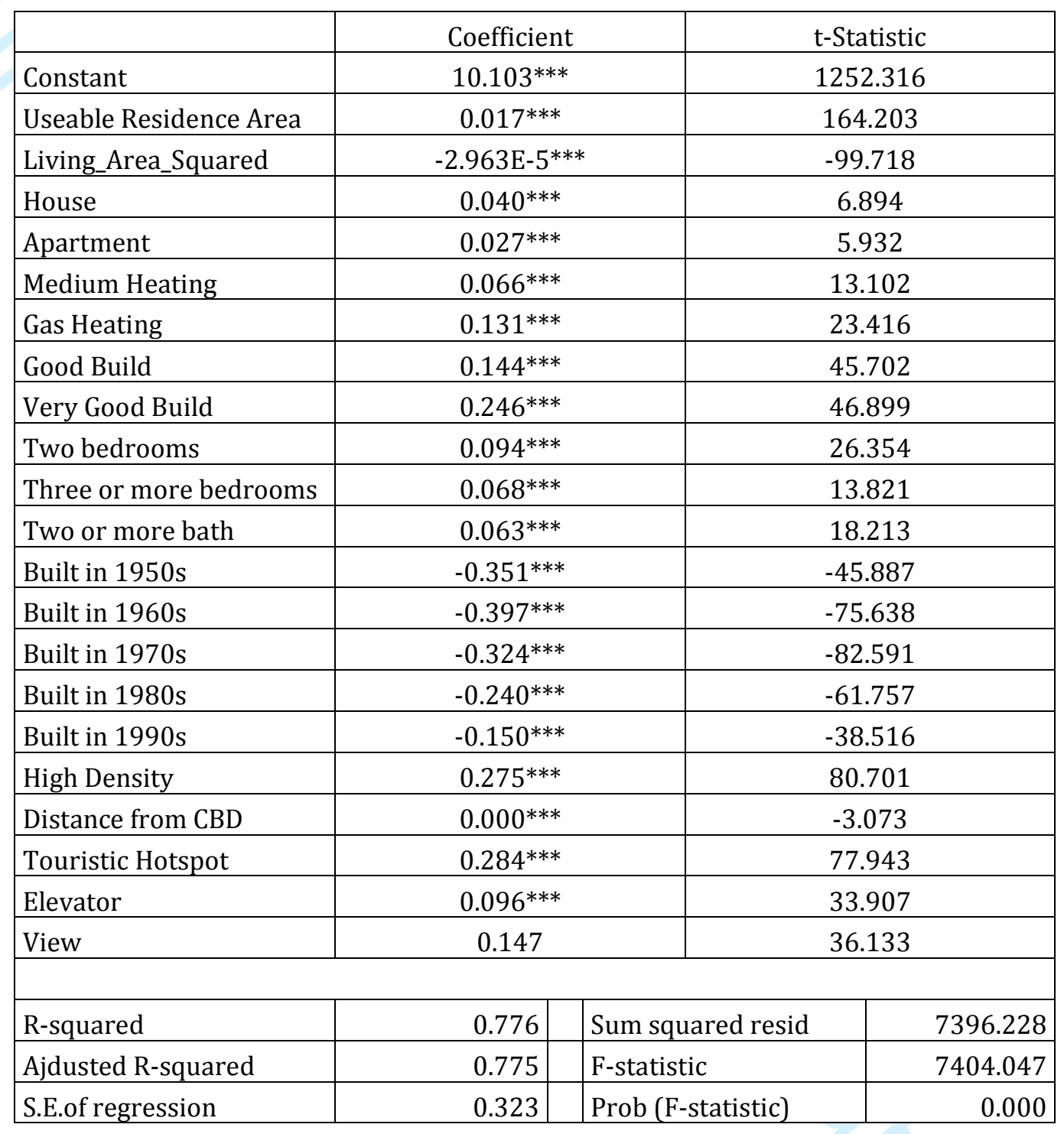

$* * *, * *, *$ indicates significance at the $1 \%, 5 \%$ and $10 \%$ levels respectively

Table 3: Levin, Lin \& Chu Panel Unit Root Test

\begin{tabular}{|c|c|}
\hline Null Hypothesis: Unit root (common u & \\
\hline Automatic lag length selection based & \\
\hline Newey-West automatic bandwidth se & ett kernel \\
\hline Total number of observations: 80 & \\
\hline Cross-sections included: 12 & \\
\hline & Statistic \\
\hline $\begin{array}{l}\text { Household Disposable Income (First } \\
\text { Difference) }\end{array}$ & $-2.79820^{* * *}$ \\
\hline House Valuation (First Difference) & $-5.27977^{* * *}$ \\
\hline
\end{tabular}

$* * *, * *, *$ indicates significance at the $1 \%, 5 \%$ and $10 \%$ levels respectively 
Table 4: Panel Model (105 observations after lagging)

\begin{tabular}{|c|c|c|c|}
\hline & Coefficient & \multicolumn{2}{|c|}{ t-Statistic } \\
\hline $\begin{array}{l}\text { One period lag on Fitted } \\
\text { Survey Value }\end{array}$ & $0.626^{* *}$ & \multicolumn{2}{|c|}{3.288} \\
\hline $\begin{array}{l}\text { Household Disposable } \\
\text { Income }\end{array}$ & $0.870^{* * *}$ & \multicolumn{2}{|c|}{4.946} \\
\hline \multicolumn{4}{|c|}{ Regional Fixed Effects (Cross) } \\
\hline $\begin{array}{l}\text { Eastern Macedonia \& } \\
\text { Thrace }\end{array}$ & $-0.227^{* * *}$ & \multicolumn{2}{|c|}{-5.413} \\
\hline Central Macedonia & $-0.332^{* * *}$ & \multicolumn{2}{|c|}{-7.219} \\
\hline Western Macedonia & $-0.386^{* * *}$ & \multicolumn{2}{|c|}{-9.649} \\
\hline Thessalia & $-0.276^{* * *}$ & \multicolumn{2}{|c|}{-8.118} \\
\hline Sterea Ellada & $-0.156^{* * *}$ & \multicolumn{2}{|c|}{-4.217} \\
\hline Peloponissos & $-0.087^{* * *}$ & \multicolumn{2}{|c|}{-11.366} \\
\hline Crete & $0.032^{* * *}$ & \multicolumn{2}{|c|}{4.648} \\
\hline Cyclades & $0.144^{* * *}$ & \multicolumn{2}{|c|}{9.569} \\
\hline West Attica & $0.183^{* * *}$ & \multicolumn{2}{|c|}{11.436} \\
\hline East Attica & $0.363^{* * *}$ & \multicolumn{2}{|c|}{14.517} \\
\hline Athens & $0.238^{* * *}$ & \multicolumn{2}{|c|}{14.105} \\
\hline Ipiros & $0.044^{* * *}$ & \multicolumn{2}{|c|}{2.838} \\
\hline Ionia Nissia & 0.815 & \multicolumn{2}{|c|}{1.466} \\
\hline Vorio Egeo & $0.022^{* * *}$ & \multicolumn{2}{|c|}{5.514} \\
\hline Dodecanisa & $-0.187^{* * *}$ & & \\
\hline R-squared & 0.654 & Mean dependent var & 11.7107 \\
\hline Ajdusted R-squared & 0.621 & S.D. dependent var & 0.68205 \\
\hline Prob (F-statistic) & 0.000 & Durbin Watson stat & 0.981503 \\
\hline
\end{tabular}

$* * *, * *,{ }^{*}$ indicates significance at the $1 \%, 5 \%$ and $10 \%$ levels respectively 
Table 5: Athens - 2007q2 - 2014q4

\begin{tabular}{|c|c|c|c|c|}
\hline \multicolumn{5}{|c|}{ Dependent Variable: House Value Index } \\
\hline \multicolumn{5}{|c|}{ Total pool (balanced) observations: 217} \\
\hline \multicolumn{5}{|c|}{ 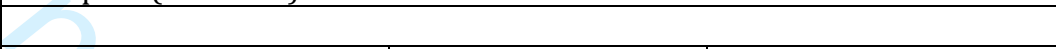 } \\
\hline Variable & \multicolumn{2}{|c|}{ Coefficient } & \multicolumn{2}{|c|}{ t-Statistic } \\
\hline \multicolumn{5}{|l|}{ 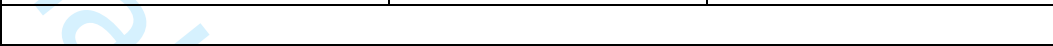 } \\
\hline GDP & \multicolumn{2}{|c|}{$2.191807^{* * *}$} & \multicolumn{2}{|c|}{9.506501} \\
\hline Housing Investment & \multicolumn{2}{|c|}{-0.015604} & \multicolumn{2}{|c|}{-0.584177} \\
\hline Fitted Unemployment & \multicolumn{2}{|c|}{$-0.623606^{* * *}$} & \multicolumn{2}{|c|}{-7.734156} \\
\hline Housing Loans & \multicolumn{2}{|c|}{-0.057038} & \multicolumn{2}{|c|}{-0.299079} \\
\hline \multicolumn{5}{|l|}{ Fixed Effects } \\
\hline Central Athens & \multicolumn{2}{|c|}{$-6.073648^{* * *}$} & \multicolumn{2}{|c|}{-3.556040} \\
\hline $\begin{array}{c}\text { North \& East Central } \\
\text { Athens }\end{array}$ & \multicolumn{2}{|c|}{$-6.542024^{* * *}$} & \multicolumn{2}{|c|}{-3.829660} \\
\hline $\begin{array}{c}\text { South \& East Central } \\
\text { Athens }\end{array}$ & \multicolumn{2}{|c|}{$-6.199826 * * *$} & \multicolumn{2}{|c|}{-3.630113} \\
\hline Middle-Northern Athens & \multicolumn{2}{|c|}{$-6.458047^{* * *}$} & \multicolumn{2}{|c|}{-3.781483} \\
\hline North Suburbs of Athens & \multicolumn{2}{|c|}{$-6.020194^{* * *}$} & \multicolumn{2}{|c|}{-3.525121} \\
\hline West Suburbs of Athens & \multicolumn{2}{|c|}{$-5.874265^{* * *}$} & \multicolumn{2}{|c|}{-3.439662} \\
\hline South Suburbs of Athens & \multicolumn{2}{|c|}{$-5.907823^{* * *}$} & \multicolumn{2}{|c|}{-3.459332} \\
\hline \multicolumn{5}{|c|}{+} \\
\hline & \multicolumn{2}{|c|}{ Weighted Statistics } & & \\
\hline \multicolumn{5}{|c|}{ 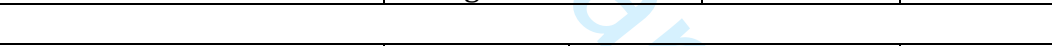 } \\
\hline R-squared & 0.985096 & \multicolumn{2}{|c|}{ Mean dependent var } & 28.77757 \\
\hline Adjusted R-squared & 0.984372 & \multicolumn{2}{|c|}{ S.D. dependent var } & 34.57677 \\
\hline Prob(F-statistic) & 0.000000 & & & \\
\hline & Unweighted & Statistics & $V_{1}$ & \\
\hline R-squared & 0.828077 & Mean de & pendent var & 5.041001 \\
\hline Sum squared resid & 3.164416 & Durbin-V & Natson stat & 1.788001 \\
\hline
\end{tabular}

$* * *, * *, *$ indicates significance at the $1 \%, 5 \%$ and $10 \%$ levels respectively 
Table 6: Thessaloniki - 2007q1 - 2014q4

\begin{tabular}{|c|c|c|c|c|}
\hline \multicolumn{5}{|c|}{ Dependent Variable: House Value Index } \\
\hline \multicolumn{5}{|c|}{ Total pool (balanced) observations: 160} \\
\hline \multicolumn{5}{|l|}{$2=$} \\
\hline Variable & \multicolumn{2}{|c|}{ Coefficient } & \\
\hline \multicolumn{3}{|l|}{ 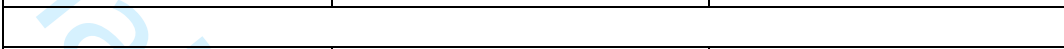 } & \multicolumn{2}{|c|}{ t-Statistic } \\
\hline GVA & \multicolumn{2}{|c|}{$0.216200^{* * *}$} & \multicolumn{2}{|c|}{4.939869} \\
\hline Housing Investment & \multicolumn{2}{|c|}{$-0.085362^{* * *}$} & \multicolumn{2}{|c|}{-4.798107} \\
\hline Housing Loans & \multicolumn{2}{|c|}{$-0.401603^{* * *}$} & \multicolumn{2}{|c|}{-5.556771} \\
\hline Unemployment & \multicolumn{2}{|c|}{$-0.079078^{* *}$} & \multicolumn{2}{|c|}{-2.218764} \\
\hline \multicolumn{5}{|l|}{ Fixed Effects } \\
\hline Thessaloniki & \multicolumn{2}{|c|}{$4.905949 * * *$} & \multicolumn{2}{|c|}{9.768836} \\
\hline $\begin{array}{c}\text { Central and East } \\
\text { Thessaloniki } \\
\end{array}$ & \multicolumn{2}{|c|}{$5.439618^{* * *}$} & \multicolumn{2}{|c|}{10.83149} \\
\hline Western Thessaloniki & \multicolumn{2}{|c|}{$5.647977^{* * *}$} & \multicolumn{2}{|c|}{11.24638} \\
\hline $\begin{array}{l}\text { Suburbs of } \\
\text { Thessaloniki }\end{array}$ & \multicolumn{2}{|c|}{$4.921751^{* * *}$} & \multicolumn{2}{|c|}{9.800302} \\
\hline $\begin{array}{l}\text { Rest of Thessaloniki } \\
\text { Prefecture }\end{array}$ & \multicolumn{2}{|c|}{$4.727790^{* * *}$} & \multicolumn{2}{|c|}{9.414083} \\
\hline \multicolumn{5}{|c|}{ 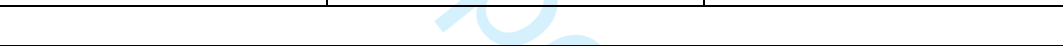 } \\
\hline R-squared & \multicolumn{3}{|c|}{\begin{tabular}{l|l}
0.978805 & Mean dependent var \\
\end{tabular}} & 4.549772 \\
\hline Adjusted R-squared & \multicolumn{3}{|c|}{\begin{tabular}{|l|l|}
0.977682 & S.D. dependent var \\
\end{tabular}} & 0.371334 \\
\hline F-statistic & \multicolumn{3}{|c|}{871.6639 Durbin-Watson stat } & 1.222494 \\
\hline Prob(F-statistic) & 0.000000 & & & \\
\hline
\end{tabular}

$* * *, * *, *$ indicates significance at the $1 \%, 5 \%$ and $10 \%$ levels respectively 
Appendix: Regional Regressions: Summary diagnostics and coefficients on independent variables in the house value models.

Table A1* West Attica to Peloponissos

\begin{tabular}{|c|c|c|c|c|c|c|c|}
\hline & West Attica & East Attica & $\begin{array}{c}\text { Eastern Macedonia } \\
\& \text { Thrace } \\
\end{array}$ & $\begin{array}{c}\text { Western } \\
\text { Macedonia }\end{array}$ & Thessalia & Sterea Ellada & Peloponissos \\
\hline (Constant) & $\begin{array}{r}10.316 \\
(152.359) \\
\end{array}$ & $\begin{array}{r}10.492 \\
(260.056) \\
\end{array}$ & $\begin{array}{r}10.034 \\
(235.825) \\
\end{array}$ & $\begin{array}{r}10.101 \\
(147.913) \\
\end{array}$ & $\begin{array}{r}10.092 \\
(316.471) \\
\end{array}$ & $\begin{array}{r}9.956 \\
(197.012) \\
\end{array}$ & $\begin{array}{r}10.355 \\
(217.591) \\
\end{array}$ \\
\hline Useable Residence Area & $\begin{array}{r}.012 \\
(15.628) \\
\end{array}$ & $\begin{array}{r}.015 \\
(38.534) \\
\end{array}$ & $\begin{array}{r}.016 \\
(30.967) \\
\end{array}$ & $\begin{array}{r}.016 \\
(26.028) \\
\end{array}$ & $\begin{array}{r}.015 \\
(35.479) \\
\end{array}$ & $\begin{array}{r}.017 \\
(31.175) \\
\end{array}$ & $\begin{array}{r}.016 \\
(29.216) \\
\end{array}$ \\
\hline Living_Area_Squared & $\begin{array}{r}-1.967 \mathrm{E}-5 \\
(-8.843) \\
\end{array}$ & $\begin{array}{r}-2.278 \mathrm{E}-5 \\
(-23.967) \\
\end{array}$ & $\begin{array}{r}-3.079 \mathrm{E}-5 \\
(-19.372) \\
\end{array}$ & $\begin{array}{r}-2.856 \mathrm{E}-5 \\
(-14.735) \\
\end{array}$ & $\begin{array}{r}-2.850 \mathrm{E}-5 \\
(-22.122) \\
\end{array}$ & $\begin{array}{r}-3.323 \mathrm{E}-5 \\
(-20.935) \\
\end{array}$ & $\begin{array}{r}-2.907 \mathrm{E}-5 \\
(-18.734) \\
\end{array}$ \\
\hline House & $\begin{array}{r}-.033 \\
(-0.692) \\
\end{array}$ & $\begin{array}{r}.019 \\
(1.023) \\
\end{array}$ & $\begin{array}{r}.148 \\
(5.086) \\
\end{array}$ & $\begin{array}{r}.136 \\
(2.838) \\
\end{array}$ & $\begin{array}{r}.081 \\
(2.673) \\
\end{array}$ & $\begin{array}{r}.202 \\
(7.953) \\
\end{array}$ & $\begin{array}{r}.194 \\
(5.190) \\
\end{array}$ \\
\hline Apartment & $\begin{array}{r}.106 \\
(3.995)\end{array}$ & $\begin{array}{r}.094 \\
(6.041)\end{array}$ & $\begin{array}{r}.069 \\
(3.388)\end{array}$ & $\begin{array}{r}-.128 \\
(-5.719)\end{array}$ & $\begin{array}{r}-.007 \\
(-0.444)\end{array}$ & $\begin{array}{r}.135 \\
(7.987) \\
\end{array}$ & $\begin{array}{r}.117 \\
(5.799)\end{array}$ \\
\hline MedHeat & $\begin{array}{r}.175 \\
(4.767) \\
\end{array}$ & $\begin{array}{r}.013 \\
(0.447) \\
\end{array}$ & $\begin{array}{r}.063 \\
(2.480) \\
\end{array}$ & $\begin{array}{r}.128 \\
(3.226) \\
\end{array}$ & $\begin{array}{r}.045 \\
(2.503) \\
\end{array}$ & $\begin{array}{r}.145 \\
(4.382) \\
\end{array}$ & $\begin{array}{r}.061 \\
(2.503) \\
\end{array}$ \\
\hline GasHeat & $\begin{array}{r}.303 \\
(7.507) \\
\end{array}$ & $\begin{array}{r}.090 \\
(2.952) \\
\end{array}$ & $\begin{array}{r}.107 \\
(3.863) \\
\end{array}$ & $\begin{array}{r}.085 \\
(1.994)\end{array}$ & $\begin{array}{r}.066 \\
(2.977) \\
\end{array}$ & $\begin{array}{r}.170 \\
(4.894) \\
\end{array}$ & $\begin{array}{r}.151 \\
(5.615) \\
\end{array}$ \\
\hline GoodBuild & $\begin{array}{r}.127 \\
(5.369) \\
\end{array}$ & $\begin{array}{r}.188 \\
(12.215) \\
\end{array}$ & $\begin{array}{r}.131 \\
(8.521) \\
\end{array}$ & $\begin{array}{r}.056 \\
(2.904)\end{array}$ & $\begin{array}{r}.111 \\
(7.830) \\
\end{array}$ & $\begin{array}{r}.100 \\
(5.953) \\
\end{array}$ & $\begin{array}{r}.112 \\
(6.555)\end{array}$ \\
\hline VGBuild & $\begin{array}{r}.232 \\
(5.211) \\
\end{array}$ & $\begin{array}{r}.252 \\
(10.382) \\
\end{array}$ & $\begin{array}{r}.217 \\
(7.927) \\
\end{array}$ & $\begin{array}{r}.083 \\
(3.316) \\
\end{array}$ & $\begin{array}{r}.249 \\
(11.482) \\
\end{array}$ & $\begin{array}{r}.255 \\
(11.506) \\
\end{array}$ & $\begin{array}{r}.321 \\
(11.426) \\
\end{array}$ \\
\hline Bed2 & $\begin{array}{r}.133 \\
(4.510) \\
\end{array}$ & $\begin{array}{r}.116 \\
(7.433) \\
\end{array}$ & $\begin{array}{r}.045 \\
(2.552) \\
\end{array}$ & $\begin{array}{r}.023 \\
(1.049) \\
\end{array}$ & $\begin{array}{r}.097 \\
(5.970) \\
\end{array}$ & $\begin{array}{r}.166 \\
(8.627) \\
\end{array}$ & $\begin{array}{r}.084 \\
(4.461) \\
\end{array}$ \\
\hline Bed3p & $\begin{array}{r}.222 \\
(5.996) \\
\end{array}$ & $\begin{array}{r}.073 \\
(3.737) \\
\end{array}$ & $\begin{array}{r}.022 \\
(0.895) \\
\end{array}$ & $\begin{array}{r}-.017 \\
(-0.620)\end{array}$ & $\begin{array}{r}.083 \\
(3.978) \\
\end{array}$ & $\begin{array}{r}.156 \\
(6.069) \\
\end{array}$ & $\begin{array}{r}.118 \\
(4.539)\end{array}$ \\
\hline Bath2p & $\begin{array}{r}-.060 \\
(-2.447) \\
\end{array}$ & $\begin{array}{r}.060 \\
(4.211) \\
\end{array}$ & $\begin{array}{r}.025 \\
(1.445) \\
\end{array}$ & $\begin{array}{r}-.001 \\
(-0.064) \\
\end{array}$ & $\begin{array}{r}.041 \\
(2.858) \\
\end{array}$ & $\begin{array}{r}.008 \\
(0.479) \\
\end{array}$ & $\begin{array}{r}-.060 \\
(-3.352) \\
\end{array}$ \\
\hline B1950s & $\begin{array}{r}-.257 \\
(-3.808) \\
\end{array}$ & $\begin{array}{r}-.183 \\
(-2.850) \\
\end{array}$ & $\begin{array}{r}-.121 \\
(-3.253) \\
\end{array}$ & $\begin{array}{r}-.356 \\
(-7.521) \\
\end{array}$ & $\begin{array}{r}-.278 \\
(-9.188) \\
\end{array}$ & $\begin{array}{r}-.283 \\
(-7.831) \\
\end{array}$ & $\begin{array}{r}-.449 \\
(-11.947) \\
\end{array}$ \\
\hline B1960s & $\begin{array}{r}-.272 \\
(-5.137) \\
\end{array}$ & $\begin{array}{r}-.251 \\
(-6.284) \\
\end{array}$ & $\begin{array}{r}-.181 \\
(-5.685) \\
\end{array}$ & $\begin{array}{r}-.281 \\
(-7.409) \\
\end{array}$ & $\begin{array}{r}-.323 \\
(-10.115) \\
\end{array}$ & $\begin{array}{r}-.317 \\
(-10.234) \\
\end{array}$ & $\begin{array}{r}-.337 \\
(-9.268) \\
\end{array}$ \\
\hline B1970s & $\begin{array}{r}-.277 \\
(-8.988) \\
\end{array}$ & $\begin{array}{r}-.251 \\
(-12.108) \\
\end{array}$ & $\begin{array}{r}-.170 \\
(-8.935) \\
\end{array}$ & $\begin{array}{r}-.329 \\
(-15.343)\end{array}$ & $\begin{array}{r}-.298 \\
(-16.558) \\
\end{array}$ & $\begin{array}{r}-.353 \\
(-17.782) \\
\end{array}$ & $\begin{array}{r}-.298 \\
(-13.857) \\
\end{array}$ \\
\hline
\end{tabular}




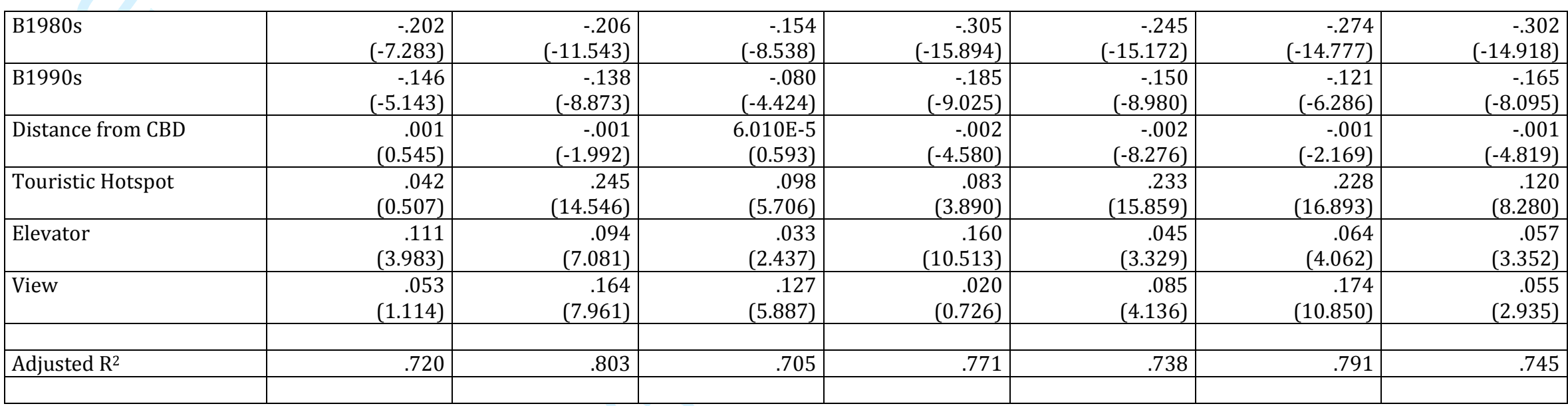

*t-Statistics in parentheses 
Table A2* Crete to Dodecanisa

\begin{tabular}{|c|c|c|c|c|c|c|}
\hline & Crete & Cyclades & Athens & Ipeiros & $\begin{array}{c}\text { Central } \\
\text { Macedonia }\end{array}$ & Dodecanisa \\
\hline (Constant) & $\begin{array}{r}10.205 \\
(319.968)\end{array}$ & $\begin{array}{r}10.219 \\
(113.132)\end{array}$ & $\begin{array}{r}10.160 \\
(623.112)\end{array}$ & $\begin{array}{r}9.938 \\
(161.926)\end{array}$ & $\begin{array}{r}10.028 \\
(292.589) \\
\end{array}$ & $\begin{array}{r}10.391 \\
(219.618)\end{array}$ \\
\hline $\begin{array}{l}\text { Useable Residence } \\
\text { Area }\end{array}$ & $\begin{array}{r}.017 \\
(39.091) \\
\end{array}$ & $\begin{array}{r}.016 \\
(19.455) \\
\end{array}$ & $\begin{array}{r}.019 \\
(101.784) \\
\end{array}$ & $\begin{array}{r}.017 \\
(20.276) \\
\end{array}$ & $\begin{array}{r}.015 \\
(37.359) \\
\end{array}$ & $\begin{array}{r}.015 \\
(21.892) \\
\end{array}$ \\
\hline Living_Area_Squared & $\begin{array}{r}-3.069 \mathrm{E}-5 \\
(-23.870)\end{array}$ & $\begin{array}{r}-2.793 \mathrm{E}-5 \\
(-11.181)\end{array}$ & $\begin{array}{r}-3.402 \mathrm{E}-5 \\
(-65.014)\end{array}$ & $\begin{array}{r}-3.472 \mathrm{E}-5 \\
(-14.281)\end{array}$ & $\begin{array}{r}-2.640 \mathrm{E}-5 \\
(-21.565)\end{array}$ & $\begin{array}{r}-2.432 \mathrm{E}-5 \\
(-12.892)\end{array}$ \\
\hline House & $\begin{array}{r}.040 \\
(1.497) \\
\end{array}$ & $\begin{array}{r}.066 \\
(1.801) \\
\end{array}$ & $\begin{array}{r}-.066 \\
(-5.383) \\
\end{array}$ & $\begin{array}{r}-.011 \\
(-0.232) \\
\end{array}$ & $\begin{array}{r}.164 \\
(9.797) \\
\end{array}$ & $\begin{array}{r}.121 \\
(3.068) \\
\end{array}$ \\
\hline Apartment & $\begin{array}{r}-.042 \\
(-2.788)\end{array}$ & $\begin{array}{r}.062 \\
(2.211) \\
\end{array}$ & $\begin{array}{r}.020 \\
(1.526)\end{array}$ & $\begin{array}{r}.008 \\
(0.250)\end{array}$ & $\begin{array}{r}.005 \\
(0.370) \\
\end{array}$ & $\begin{array}{r}.023 \\
(1.053)\end{array}$ \\
\hline MedHeat & $\begin{array}{r}.115 \\
(6.032)\end{array}$ & $\begin{array}{r}.084 \\
(2.727) \\
\end{array}$ & $\begin{array}{r}.107 \\
(8.744)\end{array}$ & $\begin{array}{r}.217 \\
(5.165)\end{array}$ & $\begin{array}{r}.013 \\
(0.777)\end{array}$ & $\begin{array}{r}.002 \\
(0.100)\end{array}$ \\
\hline GasHeat & $\begin{array}{r}.157 \\
(7.335) \\
\end{array}$ & $\begin{array}{r}.107 \\
(2.985) \\
\end{array}$ & $\begin{array}{r}.148 \\
(11.415) \\
\end{array}$ & $\begin{array}{r}.345 \\
(7.624) \\
\end{array}$ & $\begin{array}{r}.032 \\
(1.777) \\
\end{array}$ & $\begin{array}{r}.050 \\
(1.760) \\
\end{array}$ \\
\hline GoodBuild & $\begin{array}{r}.142 \\
(9.208)\end{array}$ & $\begin{array}{r}.213 \\
(5.550)\end{array}$ & $\begin{array}{r}.152 \\
(29.605)\end{array}$ & $\begin{array}{r}.216 \\
(8.400)\end{array}$ & $\begin{array}{r}.132 \\
(9.729)\end{array}$ & $\begin{array}{r}.180 \\
(8.197)\end{array}$ \\
\hline VGBuild & $\begin{array}{r}.256 \\
(11.856) \\
\end{array}$ & $\begin{array}{r}.390 \\
(8.883)\end{array}$ & $\begin{array}{r}.256 \\
(27.081)\end{array}$ & $\begin{array}{r}.289 \\
(6.693)\end{array}$ & $\begin{array}{r}.248 \\
(12.566)\end{array}$ & $\begin{array}{r}.296 \\
(9.033)\end{array}$ \\
\hline Bed2 & $\begin{array}{r}.135 \\
(7.857) \\
\end{array}$ & $\begin{array}{r}.035 \\
(1.109) \\
\end{array}$ & $\begin{array}{r}.071 \\
(11.992) \\
\end{array}$ & $\begin{array}{r}.141 \\
(4.874) \\
\end{array}$ & $\begin{array}{r}.052 \\
(3.849) \\
\end{array}$ & $\begin{array}{r}.143 \\
(5.250) \\
\end{array}$ \\
\hline Bed3p & $\begin{array}{r}.116 \\
(5.285) \\
\end{array}$ & $\begin{array}{r}.031 \\
(0.721) \\
\end{array}$ & $\begin{array}{r}.053 \\
(6.268) \\
\end{array}$ & $\begin{array}{r}.100 \\
(2.507) \\
\end{array}$ & $\begin{array}{r}.008 \\
(0.437) \\
\end{array}$ & $\begin{array}{r}.166 \\
(4.922) \\
\end{array}$ \\
\hline Bath2p & $\begin{array}{r}.017 \\
(1.147) \\
\end{array}$ & $\begin{array}{r}.056 \\
(1.824) \\
\end{array}$ & $\begin{array}{r}.052 \\
(8.534) \\
\end{array}$ & $\begin{array}{r}.019 \\
(0.706) \\
\end{array}$ & $\begin{array}{r}.044 \\
(3.740) \\
\end{array}$ & $\begin{array}{r}-.012 \\
(-0.534) \\
\end{array}$ \\
\hline B1950s & $\begin{array}{r}-.353 \\
(-12.072) \\
\end{array}$ & $\begin{array}{r}-.163 \\
(-3.525) \\
\end{array}$ & $\begin{array}{r}-.411 \\
(-32.727) \\
\end{array}$ & $\begin{array}{r}-.474 \\
(-6.592) \\
\end{array}$ & $\begin{array}{r}-.394 \\
(-13.465) \\
\end{array}$ & $\begin{array}{r}-.196 \\
(-3.393) \\
\end{array}$ \\
\hline
\end{tabular}




\begin{tabular}{|c|c|c|c|c|c|c|}
\hline B1960s & $\begin{array}{r}-.251 \\
(-7.161) \\
\end{array}$ & $\begin{array}{r}-.324 \\
(-3.705)\end{array}$ & $\begin{array}{r}-.401 \\
(-50.132) \\
\end{array}$ & $\begin{array}{r}-.235 \\
(-3.946)\end{array}$ & $\begin{array}{r}-.266 \\
(-9.046)\end{array}$ & $\begin{array}{r}-.302 \\
(-6.253) \\
\end{array}$ \\
\hline B1970s & $\begin{array}{r}-.273 \\
(-14.616)\end{array}$ & $\begin{array}{r}-.259 \\
(-4.061)\end{array}$ & $\begin{array}{r}-.348 \\
(-53.330)\end{array}$ & $\begin{array}{r}-.183 \\
(-6.121)\end{array}$ & $\begin{array}{r}-.307 \\
(-19.378)\end{array}$ & $\begin{array}{r}-.223 \\
(-8.445)\end{array}$ \\
\hline B1980s & $\begin{array}{r}-.295 \\
(-18.193)\end{array}$ & $\begin{array}{r}-.238 \\
(-5.790) \\
\end{array}$ & $\begin{array}{r}-.251 \\
(-36.850) \\
\end{array}$ & $\begin{array}{r}-.192 \\
(-6.773) \\
\end{array}$ & $\begin{array}{r}-.265 \\
(-18.769) \\
\end{array}$ & $\begin{array}{r}-.203 \\
(-8.464) \\
\end{array}$ \\
\hline B1990s & $\begin{array}{r}-.200 \\
(-11.935)\end{array}$ & $\begin{array}{r}-.044 \\
(-1.436)\end{array}$ & $\begin{array}{r}-.163 \\
(-23.354) \\
\end{array}$ & $\begin{array}{r}-.134 \\
(-5.001) \\
\end{array}$ & $\begin{array}{r}-.201 \\
(-14.865)\end{array}$ & $\begin{array}{r}-.171 \\
(-6.657) \\
\end{array}$ \\
\hline Distance from CBD & $\begin{array}{r}-.001 \\
(-6.036) \\
\end{array}$ & $\begin{array}{r}.000 \\
(-0.418) \\
\end{array}$ & $\begin{array}{r}.018 \\
(32.617) \\
\end{array}$ & $\begin{array}{r}-.001 \\
(-3.704) \\
\end{array}$ & $\begin{array}{r}.000 \\
(1.340) \\
\end{array}$ & $\begin{array}{r}-.002 \\
(-10.939) \\
\end{array}$ \\
\hline Touristic Hotspot & $\begin{array}{r}.166 \\
(14.508) \\
\end{array}$ & $\begin{array}{r}.317 \\
(6.534) \\
\end{array}$ & $\begin{array}{r}.360 \\
(45.943) \\
\end{array}$ & $\begin{array}{r}.084 \\
(3.336) \\
\end{array}$ & $\begin{array}{r}.290 \\
(24.698) \\
\end{array}$ & $\begin{array}{r}.095 \\
(5.228) \\
\end{array}$ \\
\hline Elevator & $\begin{array}{r}.124 \\
(8.006) \\
\end{array}$ & $\begin{array}{r}-.201 \\
(-0.998) \\
\end{array}$ & $\begin{array}{r}.114 \\
(25.126) \\
\end{array}$ & $\begin{array}{r}.132 \\
(5.558) \\
\end{array}$ & $\begin{array}{r}.042 \\
(3.362) \\
\end{array}$ & $\begin{array}{r}.145 \\
(4.434) \\
\end{array}$ \\
\hline View & $\begin{array}{r}.019 \\
(1.282) \\
\end{array}$ & $\begin{array}{r}.121 \\
(5.083)\end{array}$ & $\begin{array}{r}.166 \\
(23.034)\end{array}$ & $\begin{array}{r}.169 \\
(4.526) \\
\end{array}$ & $\begin{array}{r}.213 \\
(15.216)\end{array}$ & $\begin{array}{r}.104 \\
(3.422) \\
\end{array}$ \\
\hline Adjusted $\mathrm{R}^{2}$ & .823 & .738 & .811 & .757 & .715 & .842 \\
\hline
\end{tabular}

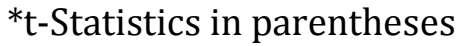

